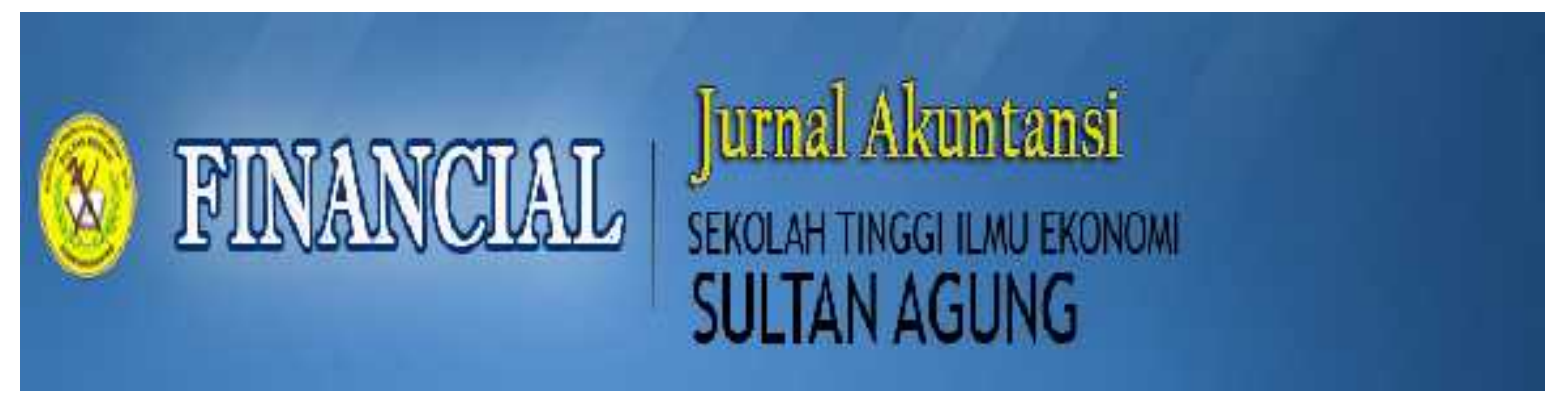

\title{
PENGARUH DEBT TO ASSETS RATIO, TOTAL ASSETS TURN OVER DAN RETURN ON ASSETS TERHADAP PRICE TO BOOK VALUE PADA PERUSAHAAN SUB \\ SEKTOR OTOMOTIF DAN KOMPONEN YANG TERDAFTAR DI BURSA EFEK INDONESIA
}

\author{
Oleh : \\ Viona Pasando \\ S1 Akuntansi \\ Jubi, Ady Inrawan, Astuti
}

\begin{abstract}
Abstrak
Tujuan dari penelitian ini adalah untuk mengetahui gambaran debt to assets Ratio, total assets turn over, return on assets dan price to book value serta pengaruh debt to assets Ratio, total assets turn over dan return on assets terhadap price to book value secara simultan maupun parsial pada Perusahaan Sub Sektor Otomotif dan Komponen yang Terdaftar di Bursa Efek Indonesia. Penelitian ini dilakukan dengan metode analisis deskriptif kualitatif dan analisis deskriptif kuantitatif. Sampel penelitian adalah Perusahaan Sub Sektor Otomotif dan Komponen yang Terdaftar di Bursa Efek Indonesia. Pengumpulan data digunakan metode dokumentasi. Teknik analisis yang digunakan adalah uji asumsi klasik, regresi linier berganda, koefisien korelasi, koefisien determinasi dan uji hipotesis.

Hasil penelitian dapat disimpulkan sebagai berikut: 1. Nilai rata-rata Debt to Assets Ratio, Total Assets Turn Over, Return On Assets dan Price to Book Value mengalami fluktuasi dan cenderung menurun. 2. Hasil regresi linear berganda diperoleh debt to assets ratio, total assets turn over dan return on assets berpengaruh positif terhadap price to book value. 3 . Hasil uji koefisien korelasi dan determinasi terdapat hubungan yang sangat kuat antara variabel independen debt to assets ratio, total assets turn over dan return on assets dengan variabel dependen price to book value, dan sisanya dipengaruhi oleh faktor lain seperti DER, perputaran persediaan, ROE dan faktor lainnya. 4. Hasil pengujian hipotesis secara simultan dapat disimpulkan bahwa debt to assets ratio, total assets turn over dan return on assets berpengaruh signifikan terhadap price to book value pada Perusahaan Sub Sektor Otomotif dan Komponen yang Terdaftar di Bursa Efek Indonesia Periode 2013-2017.

Hasil penelitian ini menyarankan sebaiknya perusahaan untuk mengurangi jumlah utang dengan meningkatkan tambahan modal, meningkatkan penjualan dan meningkatkan kinerja keuangan.
\end{abstract}

Kata Kunci: Debt to Assets Ratio (DAR), Total Assets Turn Over (TATO), Return On Assets (ROA) dan Price to Book Value (PBV)

Abstract

The purpose of this research are to know the description of debt to assets ratio, total assets turn over, return on assets and price to book value and to know the influence of debt to assets ratio, total assets turn over and return on assets to price to book value in Automotive and Components Sub-Sector Companies Listed on the Indonesia Stock Exchange as a simultaneously or partially. This research was done by using descriptive qualitative and descriptive quantitative analysis. Sample of research is the Automotive and Components Sub-Sector Companies Listed on the Indonesia Stock Exchange. Data collection is done by documentation method. The analysis 
technique used are classical assumption test, multiple linear analysis, correlation coefficient, determination coefficient and hypothesis testing.

The results can be summarized as follows: 1. Average Debt to Assets Ratio, Total Assets Turn Over, Return On Assets and Price to Book Value fluctuates and tends to decrease. 2. The results of multiple linear regression is debt to assets ratio, total assets turn over and return on assets have a positive influence on price to book value. 3 . The results of testing the correlation and determination coefficients have a very strong correlation between the independent variables of debt to assets ratio, total assets turn over and return on assets with the dependent variables price to book value, and rest is influenced by other factors such as DER, inventory turnover, ROE and other factors. 4. The results of hypothesis test on simultaneous can be conclucled that debt to assets ratio, total assets turn over and return on assets have significant incluence on price to book value in Automotive and Components Sub-Sector Companies Listed on the Indonesia Stock Exchange Period 2013-2017.

The results of this research suggest that companies should reduce the amount of debt by increasing additional capital, increasing sales and improving financial performance.

Keywords: Debt to Assets Ratio (DAR), Total Assets Turn Over (TATO), Return On Assets (ROA) and Price to Book Value (PBV)

\section{PENDAHULUAN}

\subsection{Latar Belakang Masalah}

Nilai perusahaan dapat menjadi gambaran atas keadaan perusahaan yang dapat mempengaruhi persepsi investor terhadap perusahaan yang bersangkutan. Semakin baik nilai perusahaan maka tingkat keyakinan calon investor akan semakin bertambah. Salah satu rasio untuk mengukur nilai perusahaan adalah dengan menggunakan Price to Book Value (PBV). Rasio ini memberikan indikator bagi manajemen tentang bagaimana pandangan investor terhadap resiko dan prospek perusahaan di masa depan.

Nilai perusahaan dapat dipengaruhi oleh beberapa faktor, diantaranya yaitu leverage, aktivitas dan profitabilitas. Leverage berhubungan dengan manajemen utang yaitu mencerminkan kemampuan perusahaan dalam mendanai aset dengan utang dan dapat diukur dengan Debt to Assets Ratio (DAR). Aktivitas berhubungan dengan manajemen aset yaitu mencerminkan kemampuan perusahaan dalam memanfaatkan sumber dananya melalui aset dan dapat diukur dengan Total Assets Turn Over (TATO). Sedangkan profitabilitas mencerminkan kemampuan perusahaan dalam menhasilkan laba dapat diukur dengan Return On Assets (ROA).

Menurut Brigham dan Joel (2010:150), yang menyatakan bahwa "jika rasio likuiditas, manajemen aset, manajemen utang dan profitabilitas semuanya terlihat baik dan jika kondisi ini berjalan secara terus menerus secara stabil maka rasio nilai pasar juga akan tinggi, harga saham kemungkinan tinggi sesuai dengan yang diperkirakan, dan manajemen telah melakukan pekerjaannya dengan baik sehingga sebaiknya mendapatkan imbalan".

Berikut ini adalah gambaran Debt to Assets Ratio, Total Assets Turn Over, Return On Assets dan Price to Book Value pada Perusahaan Sub Sektor Otomotif dan Komponen yang terdaftar di Bursa Efek Indonesia periode 2013-2017.

Tabel 1.1

Gambaran Debt to Assets Ratio, Total Assets Turn

Over, Return On Assets dan Price to Book Value pada Perusahaan Sub Sektor Otomotif dan

Komponen yang Terdaftar di Bursa Efek Indonesia Periode 2013-2017

\begin{tabular}{|c|c|c|c|c|}
\hline Tahun & $\begin{array}{c}\text { DAR } \\
\text { (kali) }\end{array}$ & $\begin{array}{c}\text { TATO } \\
\text { (kali) }\end{array}$ & $\begin{array}{c}\text { ROA } \\
\text { (kali) }\end{array}$ & $\begin{array}{c}\text { PBV } \\
\text { (kali) }\end{array}$ \\
\hline 2013 & 0,441 & 0,816 & 0,049 & 1,272 \\
\hline 2014 & 0,432 & 0,743 & 0,048 & 1,337 \\
\hline 2015 & 0,461 & 0,659 & 0,019 & 0,838 \\
\hline 2016 & 0,432 & 0,645 & 0,038 & 0,994 \\
\hline
\end{tabular}




\begin{tabular}{|c|c|c|c|c|}
\hline 2017 & 0,419 & 0,684 & 0,038 & 0,980 \\
\hline $\begin{array}{c}\text { Rata- } \\
\text { rata }\end{array}$ & $\mathbf{0 , 4 3 7}$ & $\mathbf{0 , 7 0 9}$ & $\mathbf{0 , 0 3 9}$ & $\mathbf{1 , 0 8 4}$ \\
\hline Sumber: Laporan & \multicolumn{3}{|c|}{ Keuangan Perusahaan } \\
Sub Sektor Otomotif dan \\
Komponen (Data Diolah)
\end{tabular}

Berdasarkan Tabel 1.1 di atas dapat diketahui bahwa DAR, TATO, ROA dan PBV pada Perusahaan Sub Sektor Otomotif dan Komponen yang terdaftar di Bursa Efek Indonesia periode 2013-2017 mengalami fluktuasi dan cenderung menurun.

\subsection{Rumusan Masalah}

1. Bagaimana gambaran Debt to Assets Ratio, Total Assets Turn Over, Return On Assets dan Price to Book Value pada Perusahaan Sub Sektor Otomotif dan Komponen yang terdaftar di Bursa Efek Indonesia.

2. Bagaimana pengaruh Debt to Assets Ratio, Total Assets Turn Over dan Return On Assets terhadap Price to Book Value secara simultan maupun parsial pada Perusahaan Sub Sektor Otomotif dan Komponen yang terdaftar di Bursa Efek Indonesia.

1.3. Tujuan Penelitian

1. Untuk mengetahui gambaran Debt to Assets Ratio, Total Assets Turn Over, Return On Assets dan Price to Book Value pada Perusahaan Sub Sektor Otomotif dan Komponen yang terdaftar di Bursa Efek Indonesia.

2. Untuk mengetahui pengaruh Debt to Assets Ratio, Total Assets Turn Over dan Return On Assets terhadap Price to Book Value secara simultan maupun parsial pada Perusahaan Sub Sektor Otomotif dan Komponen yang terdaftar di Bursa Efek Indonesia.

\subsection{Metode Penelitian}

Objek penelitian dari laporan keuangan

Perusahaan Sub Sektor Otomotif dan Komponen yang Terdaftar di Bursa Efek Indonesia selama periode 2013 sampai dengan 2017 yang telah diaudit. Penelitian ini menggunakan data sekunder dengan mengakses website http://www.idx.co.id, www.sahamok.com,

www.duniainvestasi.com.

Desain penelitian ini adalah penelitian kepustakaan (library research). Teknik analisa data yang digunakan adalah uji asumsi klasik, analisis deskriptif kualitatif dan analisis deskriptif kuantitatif.

\section{LANDASAN TEORI}

\subsection{Akuntansi}

Menurut pendapat Rudianto (2012:4), "akuntansi adalah sebuah sistem informasi yang menghasilkan informasi keuangan kepada pihak-pihak yang berkepentingan mengenai aktivitas ekonomi dan kondisi suatu perusahaan".

Martani, dkk (2012:126) mengatakan akuntansi bertujuan menyediakan informasi dalam bentuk laporan yang memuat posisi keuangan, hasil usaha dan perubahan posisi keuangan lainnya secara wajar sesuai dengan Prinsip Akuntansi Berterima Umum (PABU) atau Generally Accepted Accounting Principle (GAAP)".

\subsection{Analisa Laporan Keuangan}

Menurut Astuti (2004:29), "analisis laporan keuangan merupakan segala sesuatu yang menyangkut penggunaan informasi akuntansi untuk membuat keputusan bisnis dan investasi".

Pendapat Munawir (2010:54) analisa laporan keuangan bertujuan menginformasikan hal-hal yang berhubungan dengan posisi keuangan dan hasil-hasil yang telah dicapai perusahaan tersebut akan lebih berarti bagi pihak yang berkepentingan apabila data tersebut diperbandingkan untuk dua periode atau lebih dan dianslis lebih lanjut sehingga akan dapat diperoleh data yang akan dapat mendukung keputusan yang akan diambil."

\subsection{Debt to Assets Ratio}

Menurut Sudana (2011:20), "Debt ratio mengukur proporsi dana yang bersumber dari utang umtuk membiayai aktiva perusahaan. Semakin besar rasio menunjukkan semakin besar porsi penggunaan utang dalam membiayai investasi pada aktiva, yang berarti pula risiko 
keuangan perusahaan meningkat dan sebaliknya".

Menurut pendapat Kasmir (2010:112), "Debt to Assets Ratio (DAR) adalah rasio utang yang digunakan untuk mengukur seberapa besar aktiva perusahaan dibiayai oleh utang atau seberapa besar utang perusahaan berpengaruh terhadap pengelolaan aktiva".

\subsection{Total Assets Turn Over}

Menurut Astuti (2004:34), "perputaran total aset merupakan rasio yang digunakan untuk mengukur perputaran semua aset perusahaan".

Menurut Kasmir (2010:127), “Total Assets Turn Over (TATO) merupakan rasio yang menggambarkan perputaran aktiva diukur dari volume penjualan. Sehingga, makin besar rasio TATO makin baik artinya aktiva dapat lebih cepat berputar dan meraih laba dan menunjukkan semakin efesien penggunaan keseluruhan aktiva dalam menghasilkan penjualan. Dengan kata lain jumlah aset yang sama dapat memperbesar volume penjualan apabila Total Assets Turnover (TATO) ditingkatkan atau diperbesar".

\subsection{Return on Assets}

Menurut Horne dan John (2012:180), "return on assets (ROA) merupakan perbandingan laba bersih dengan jumlah aktiva perusahaan".

Sedangkan Sudana (2011:22)

mengemukakan ROA menunjukkan kemampuan perusahaan dengan menggunakan seluruh aktiva yang dimiliki untuk menghasilkan EAT. Rasio ini penting bagi pihak manajemen untuk mengevaluasi dan efisiensi manajemen perusahaan dalam mengelola seluruh aktiva perusahaan, semakin besar ROA berati semakin efisien pengunaan aktiva perusahaan atau dengan kata lain jumlah aktiva yang sama bisa dihasilkan laba yang lebih besar, dan sebaliknya".

\subsection{Price to Book Value}

Menurut Brigham dan Joel (2010:150), "Rasio nilai pasar / nilai buku adalah rasio harga pasar suatu saham terhadap nilai bukunya memberikan indikasi pandangan investor atas perusahaan".

Menurut Subramanyam dan John (2010:45), "Harga terhadap nilai buku (price to book value) adalah rasio pasar yang digunakan untuk mengukur kinerja harga saham terhadap nilai bukunya".

2.7. Pengaruh Debt to Assets Ratio, Total Assets Turn Over dan Return On Assets Terhadap Price to Book Value

Price to Book Value (PBV) dapat dipengaruhi oleh beberapa faktor, diantaranya yaitu leverage, aktivitas dan profitabilitas. Leverage berhubungan dengan manajemen utang yaitu mencerminkan kemampuan perusahaan dalam mendanai aset dengan utang dan dapat diukur dengan Debt to Assets Ratio (DAR). Aktivitas berhubungan dengan manajemen aset yaitu mencerminkan kemampuan perusahaan dalam memanfaatkan sumber dananya melalui aset dan dapat diukur dengan Total Assets Turn Over (TATO). Sedangkan profitabilitas mencerminkan kemampuan perusahaan dalam menghasilkan laba dapat diukur dengan Return On Assets (ROA).

Menurut Brigham dan Joel (2010:150), jika rasio likuiditas, manajemen aset, manajemen utang dan profitabilitas semuanya terlihat baik dan jika kondisi ini berjalan secara terus menerus secara stabil maka rasio nilai pasar juga akan tinggi, harga saham kemungkinan tinggi sesuai dengan yang diperkirakan, dan manajemen telah melakukan pekerjaannya dengan baik sehingga sebaiknya mendapatkan imbalan.

\section{ANALISIS DAN EVALUASI}

3.1. Analisis

\subsubsection{Analisis Deskriptif Kualitatif}

Analisis deskriptif kualitatif digunakan untuk mengetahui gambaran atau deskripsi mengenai Debt to Assets Ratio (DAR), Total Assets Turn Over (TATO), Return On Assets (ROA) dan Price to Book Value (PBV) pada Perusahaan Sub Sektor Otomotif dan Komponen yang terdaftar di Bursa Efek Indonesia selama periode 2013-2017. 
3.1.1.1. Analisis Debt to Assets Ratio pada Perusahaan Sub Sektor Otomotif dan Komponen yang terdaftar di Bursa Efek Indonesia periode 2013-2017

Debt to Assets Ratio (DAR) adalah rasio yang digunakan perusahaan untuk mengukur pengelolaan utang dengan membandingkan total utang dan total aset. Untuk rata-rata Debt to Assets Ratio (DAR) pada Perusahaan Sub Sektor Otomotif dan Komponen yang terdaftar di Bursa Efek Indonesia selama periode 2013-2017 dapat dilihat pada Tabel 3.1 sebagai berikut:

$$
\text { Tabel } 3.1
$$

Rata-rata Debt to Assets Ratio (DAR) pada

Perusahaan Sub Sektor Otomotif dan

Komponen yang terdaftar di Bursa Efek Indonesia Periode 2013-2017

\begin{tabular}{|c|c|c|c|c|c|c|}
\hline $\begin{array}{c}\text { Kode } \\
\text { Emiten }\end{array}$ & $\begin{array}{l}2013 \\
\text { (Kali) }\end{array}$ & $\begin{array}{l}2014 \\
\text { (Kali) }\end{array}$ & $\begin{array}{l}2015 \\
\text { (Kali) }\end{array}$ & $\begin{array}{l}2016 \\
\text { (Kali) }\end{array}$ & $\begin{array}{l}2017 \\
\text { (Kali) }\end{array}$ & $\begin{array}{l}\text { Rata- } \\
\text { rata }\end{array}$ \\
\hline ASII & 0,504 & 0,490 & 0,484 & 0,466 & 0,471 & 0,483 \\
\hline AUTO & 0,242 & 0,295 & 0,293 & 0,279 & 0,271 & 0,276 \\
\hline BRAM & 0,319 & 0,421 & 373 & 0,332 & 0,287 & 0,346 \\
\hline GJTL & 0,627 & 0,627 & 692 & 0,687 & 0,687 &, 664 \\
\hline INDS & 0,202 & 0,199 & 249 & 0,165 & 0,119 & 0,187 \\
\hline NIPS & 0,704 & 0,523 & 0,607 & 0,526 & 0,537 & 0,579 \\
\hline PRAS & 0,489 & 0,467 & 0,530 & 0,566 & 0,561 & 0,523 \\
\hline $\begin{array}{l}\text { Rata- } \\
\text { rata }\end{array}$ & 0,441 & 0,432 & 0,461 & 0,432 & 0,419 & 0,437 \\
\hline \multicolumn{6}{|c|}{ Nilai Minimum DAR } & 0,119 \\
\hline \multicolumn{6}{|c|}{ Nilai Maksimum DAR } & 0,704 \\
\hline \multicolumn{6}{|c|}{ Rata-rata DAR Keseluruhan } & 0,437 \\
\hline \multicolumn{7}{|c|}{ Sumber: Lap } \\
\hline & $\begin{array}{l}\text { Sub } \\
\text { Kon }\end{array}$ & & tor & $\mathrm{O}$ & & \\
\hline
\end{tabular}

Berdasarkan Tabel 3.1, dapat diketahui bahwa rata-rata Debt to Assets Ratio (DAR) pada Perusahaan Sub Sektor Otomotif dan Komponen yang Terdaftar di Bursa Efek Indonesia periode 2013-2017 mengalami fluktuasi dan cenderung menurun. Hal ini dipengaruhi oleh total utang dan total aset mengalami peningkatan tetapi total aset meningkat jauh lebih tinggi dari total utang.

3.1.1.2. Analisis Total Assets Turn Over pada Perusahaan Sub Sektor Otomotif dan Komponen yang Terdaftar di Bursa Efek Indonesia Periode 2013-2017
Total Assets Turn Over (TATO) merupakan rasio untuk mengukur perputaran semua aset pada perusahaan yang dimiliki dalam menghasilkan penjualan. Untuk ratarata Total Assets Turn Over (TATO) pada Perusahaan Sub Sektor Otomotif dan Komponen yang terdaftar di Bursa Efek Indonesia selama periode 2013-2017 dapat dilihat pada Tabel 3.2 sebagai berikut:

Tabel 3.2

Rata-rata Total Assets Turn Over (TATO) pada Perusahaan Sub Sektor Otomotif dan Komponen yang terdaftar di Bursa

Efek Indonesia Periode 2013-2017

\begin{tabular}{|c|c|c|c|c|c|c|}
\hline $\begin{array}{c}\text { Kode } \\
\text { Emit } \\
\text { en }\end{array}$ & $\begin{array}{l}2013 \\
\text { (Kali) }\end{array}$ & $\begin{array}{l}2014 \\
\text { (Kali) }\end{array}$ & $\begin{array}{l}2015 \\
\text { (Kali) }\end{array}$ & $\begin{array}{l}2016 \\
\text { (Kali) }\end{array}$ & $\begin{array}{l}2017 \\
\text { (Kali) }\end{array}$ & $\begin{array}{l}\text { Rata- } \\
\text { rata) }\end{array}$ \\
\hline ASII & 0,906 & 0,855 & 0,750 & 0,692 & 0,697 & 0,780 \\
\hline $\begin{array}{c}\text { AUT } \\
\text { O }\end{array}$ & 0,848 & 0,852 & 0,818 & 0,876 & 0,918 & 0,862 \\
\hline $\begin{array}{c}\text { BRA } \\
\text { M }\end{array}$ & 0,837 & 0,674 & 0,712 & 0,744 & 0,794 & 0,752 \\
\hline GJTL & 0,805 & 0,815 & 0,741 & 0,729 & 0,778 & 0,773 \\
\hline INDS & 0,775 & 0,818 & 0,650 & 0,661 & 0,808 & 0,742 \\
\hline NIPS & 1,141 & 0,842 & 0,638 & 0,585 & 0,567 & 0,755 \\
\hline $\begin{array}{c}\text { PRA } \\
\text { S }\end{array}$ & 0,397 & 0,346 & 0,307 & 0,230 & 0,226 & 0,301 \\
\hline $\begin{array}{c}\text { Rata- } \\
\text { rata }\end{array}$ & 0,816 & 0,743 & 0,659 & 0,645 & 0,684 & 0,709 \\
\hline \multicolumn{6}{|c|}{ Nilai Minimum TATO } & 0,226 \\
\hline \multicolumn{6}{|c|}{ Nilai Maksimum TATO } & 1,141 \\
\hline \multicolumn{6}{|c|}{ Rata-rata TATO Keseluruhan } & 0,709 \\
\hline \multirow[t]{2}{*}{ Sumb } & \multicolumn{4}{|c|}{ r: Laporan Keuangan } & \multicolumn{2}{|c|}{ Perusahaar } \\
\hline & $\mathrm{Su}$ & 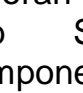 & $\begin{array}{l}\text { ektor } \\
\text { (Dat }\end{array}$ & (2) & motif & \\
\hline
\end{tabular}

Berdasarkan Tabel 3.2, dapat diketahui bahwa rata-rata Total Assets Turn Over (TATO) pada Perusahaan Sub Sektor Otomotif dan Komponen yang Terdaftar di Bursa Efek Indonesia periode 2013-2017 mengalami fluktuasi dan cenderung menurun. Hal ini dipengaruhi oleh penjualan dan total aset mengalami peningkatan tetapi total aset meningkat jauh lebih tinggi dari penjualan.

3.1.1.3. Analisis Return On Assets pada Perusahaan Sub Sektor Otomotif dan Komponen yang Terdaftar di Bursa Efek Indonesia Periode 2013-2017 
Return On Assets (ROA) adalah rasio yang digunakan untuk mengukur kemampuan perusahaan dengan perbandingan laba bersih dan jumlah aktiva. Untuk rata-rata Return on Assets (ROA) pada Perusahaan Sub Sektor Otomotif dan Komponen yang terdaftar di Bursa Efek Indonesia selama periode 2013-2017 dapat dilihat pada Tabel 3.3 sebagai berikut:

\section{Tabel 3.3}

Rata-rata Return On Assets (ROA) pada

Perusahaan Sub Sektor Otomotif dan

Komponen yang terdaftar di Bursa Efek Indonesia Periode 2013-2017

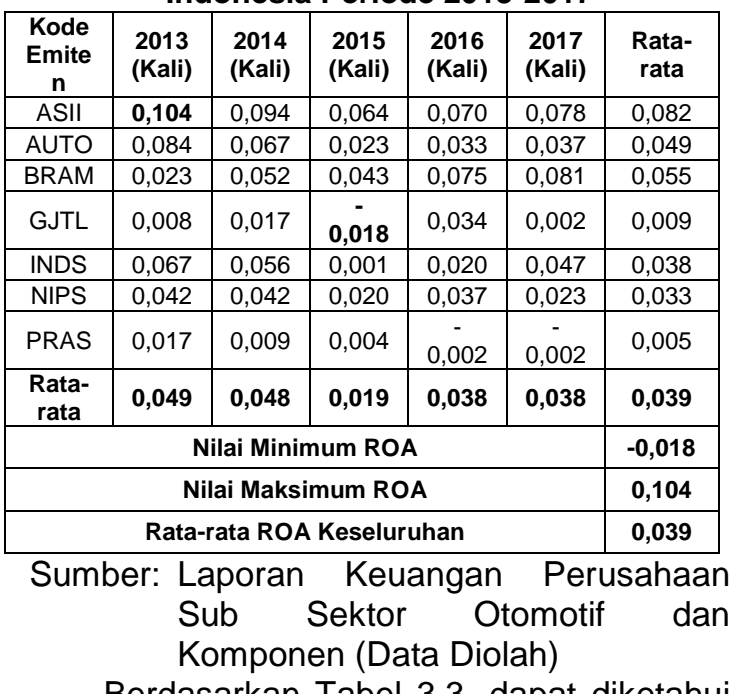

Berdasarkan Tabel 3.3, dapat diketahui bahwa rata-rata Return On Assets (ROA) pada Perusahaan Sub Sektor Otomotif dan Komponen yang Terdaftar di Bursa Efek Indonesia periode 2013-2017 mengalami fluktuasi dan cenderung menurun. Hal ini disebabkan oleh total aset meningkat sedangkan laba bersih menurun.

\subsubsection{Analisis Price to Book Value pada} Perusahaan Sub Sektor Otomotif dan Komponen yang Terdaftar di Bursa Efek Indonesia Periode 2013-2017

Price to Book Value (PBV) adalah rasio yang mengukur kinerja harga pasar perusahaan dengan nilai bukunya. Untuk rata-rata Price to Book Value (PBV) pada Perusahaan Sub Sektor Otomotif dan
Komponen yang terdaftar di Bursa Efek Indonesia selama periode 2013-2017 dapat dilihat pada Tabel 3.4 sebagai berikut:

Tabel 3.4

Rata-rata Price to Book Value (PBV) pada Perusahaan Sub Sektor Otomotif dan

Komponen yang terdaftar di Bursa Efek Indonesia selama periode 2013-2017

\begin{tabular}{|c|c|c|c|c|c|c|}
\hline $\begin{array}{c}\text { Kode } \\
\text { Emiten }\end{array}$ & $\begin{array}{c}\mathbf{2 0 1 3} \\
\text { (Kali) }\end{array}$ & $\begin{array}{c}\mathbf{2 0 1 4} \\
\text { (Kali) }\end{array}$ & $\begin{array}{c}\mathbf{2 0 1 5} \\
\text { (Kali) }\end{array}$ & $\begin{array}{c}\mathbf{2 0 1 6} \\
\text { (Kali) }\end{array}$ & $\begin{array}{c}\mathbf{2} 217 \\
\text { (Kali) }\end{array}$ & $\begin{array}{c}\text { Rata- } \\
\text { rata }\end{array}$ \\
\hline ASII & $\mathbf{3 , 2 8 0}$ & 3,144 & 2,380 & 2,992 & 2,718 & 2,903 \\
\hline AUTO & 2,041 & 2,214 & 0,841 & 1,041 & 1,016 & 1,431 \\
\hline BRAM & 0,557 & 1,125 & 1,022 & 1,169 & 1,163 & 1,007 \\
\hline GJTL & 1,023 & 0,830 & 0,342 & 0,638 & 0,417 & 0,650 \\
\hline INDS & 0,644 & 0,578 & $\mathbf{0 , 1 2 0}$ & 0,259 & 0,387 & 0,398 \\
\hline NIPS & 1,040 & 1,257 & 1,037 & 0,687 & 0,930 & 0,990 \\
\hline PRAS & 0,319 & 0,209 & 0,122 & 0,172 & 0,228 & 0,210 \\
\hline $\begin{array}{c}\text { Rata- } \\
\text { rata }\end{array}$ & $\mathbf{1 , 2 7 2}$ & $\mathbf{1 , 3 3 7}$ & $\mathbf{0 , 8 3 8}$ & $\mathbf{0 , 9 9 4}$ & $\mathbf{0 , 9 8 0}$ & $\mathbf{1 , 0 8 4}$ \\
\hline \multicolumn{6}{|c|}{ Nilai Minimum PBV } \\
\hline \multicolumn{6}{|c|}{ Nilai Maksimum PBV } & $\mathbf{0 , 1 2 0}$ \\
\hline \multicolumn{6}{|c|}{ Rata-rata PBV Keseluruhan } & $\mathbf{3 , 2 8 0}$ \\
\hline
\end{tabular}

Sumber: Laporan Keuangan Perusahaan Sub Sektor Otomotif dan Komponen (Data Diolah)

Berdasarkan Tabel 3.4, dapat diketahui bahwa rata-rata Price to Book Value (PBV) pada Perusahaan Sub Sektor Otomotif dan Komponen yang Terdaftar di Bursa Efek Indonesia periode 2013-2017 mengalami fluktuasi dan cenderung menurun. Hal ini dipengaruhi oleh peningkatan nilai buku tidak diikuti oleh harga saham.

\subsubsection{Analisis Deskriptif Kuantitatif}

\subsubsection{Analisis Regresi Linear Berganda}

Analisis regresi linear berganda bertujuan untuk menganalisis pengaruh debt to assets ratio, total assets turn over dan return on assets terhadap price to book value. Hasil pengujian dengan menggunakan analisis regresi linear berganda sebagai berikut:

Tabel 3.5

Hasil Analisis Regresi Linear Berganda Coefficients $^{a}$

\begin{tabular}{|l|r|r|r|}
\hline \multirow{2}{*}{ Model } & \multicolumn{2}{|c|}{$\begin{array}{c}\text { Unstandardized } \\
\text { Coefficients }\end{array}$} & $\begin{array}{c}\text { Standardized } \\
\text { Coefficients }\end{array}$ \\
\cline { 2 - 4 } & \multicolumn{1}{|c|}{ B } & \multicolumn{1}{c|}{$\begin{array}{c}\text { Std. } \\
\text { Error }\end{array}$} & \multicolumn{1}{c|}{ Beta } \\
\hline (Constant) &,- 872 &, 400 &, 344 \\
DAR & 1,853 &, 515 &, 340 \\
TATO &, 181 &, 462 &, 040 \\
ROA & 26,348 & 3,147 &, 908 \\
\hline
\end{tabular}


a. Dependent Variable: PBV

Sumber: Hasil Pengolahan Data SPSS 21 (2018)

Berdasarkan Tabel 3.5 di atas, model persamaan regresi yang diperoleh adalah:

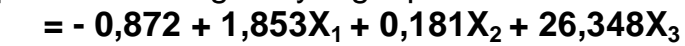

Artinya debt to assets ratio, total assets turn over dan return on assets berpengaruh positif terhadap price to book value pada Perusahaan Sub Sektor Otomotif dan Komponen yang Terdaftar di Bursa Efek Indonesia periode 2013-2017.

\subsubsection{Koefisien Korelasi dan Determinasi}

Hasil pengujian dengan menggunakan koefisien korelasi dan korelasi determinasi sebagai berikut:

Tabel 3.6

Hasil Analisis Koefisien Korelasi dan Koefisien Determinasi Model Summary

\begin{tabular}{|c|r|r|r|r|}
\hline Model & $\mathrm{R}$ & $\begin{array}{c}\mathrm{R} \\
\text { Square }\end{array}$ & $\begin{array}{c}\text { Adjusted } \\
\mathrm{R} \text { Square }\end{array}$ & $\begin{array}{r}\text { Std. Error of } \\
\text { the Estimate }\end{array}$ \\
\hline 1 &, 867 &, 752 &, 728 &, 468534 \\
\hline
\end{tabular}

a. Predictors: (Constant), ROA, DAR, TATO

b. Dependent Variable: PBV

Sumber: Hasil Pengolahan Data SPSS 21 (2018)

Berdasarkan Tabel 3.6 di atas, dapat dilihat bahwa nilai korelasi $(r)$ adalah 0,867 yang artinya bahwa terdapat hubungan yang sangat kuat antara variabel debt to assets ratio, total assets turn over dan return on assets dengan price to book value. Sementara koefisien determinasi (R Square) adalah 0,752 yang artinya bahwa tinggi rendahnya PBV dapat dijelaskan oleh variabel ROA, DAR dan TATO sebesar $75,2 \%$ sedangkan sisanya $25,8 \%$ dijelaskan oleh faktor lainnya yang tidak dijelaskan dalam penelitian ini seperti DER, perputaran persediaan, ROE dan faktor lainnya.

\subsubsection{Uji Hipotesis}

\section{Uji Simultan (Uji F)}

Hasil uji $F$ dalam penelitian ini dapat disajikan dalam Tabel 3.7 sebagai berikut:
Tabel 3.7

Hasil Uji F

ANOVA $^{a}$

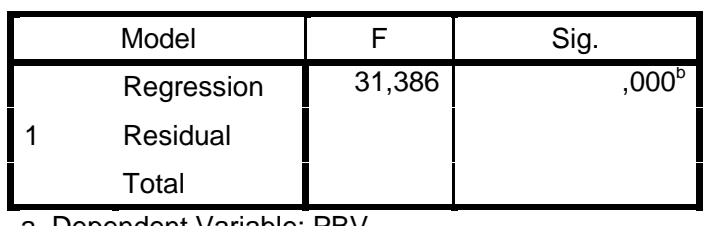

a. Dependent Variable: PBV

b. Predictors: (Constant), ROA, DAR, TATO

Sumber: Hasil Pengolahan Data SPSS 21 (2018)

Berdasarkan Tabel 3.7 di atas, dapat dilihat nilai $F_{\text {hitung }}$ sebesar 31,386 . Sedangkan untuk $\mathrm{F}_{\text {tabel }}$ dengan tingkat signifikansi $5 \%$, n$\mathrm{k}-1$ atau 35-3-1=31, dari tabel $\mathrm{F}$ diperoleh angka $F_{\text {tabel }}$ sebesar 2,91. Dengan demikian, maka diperoleh $F_{\text {hitung }}$ sebesar 31,386 $>F_{\text {tabel }}$ sebesar 2,91 dengan taraf signifikan $0,000<$ 0,05 , maka $\mathrm{H}_{0}$ ditolak. Hal ini berarti debt to assets ratio, total assets turn over dan return on assets berpengaruh signifikan terhadap price to book value pada Perusahaan Sub Sektor Otomotif dan Komponen yang terdaftar di Bursa Efek Indonesia periode 2013-2017.

\section{Uji Parsial (Uji t)}

Hasil uji $\mathrm{t}$ dalam penelitian ini dapat disajikan dalam Tabel 3.8 sebagai berikut:

Tabel 3.8

Hasil Uji t

Coefficients $^{a}$

\begin{tabular}{|l|r|r|}
\hline \multicolumn{1}{|c|}{ Model } & $\mathrm{t}$ & \multicolumn{1}{|c|}{ Sig. } \\
\hline \multicolumn{1}{|c|}{ (Constant) } & $-2,182$ &, 037 \\
DAR & 3,600 &, 001 \\
TATO &, 393 &, 697 \\
\multicolumn{1}{|c|}{ ROA } & 8,373 &, 000 \\
\hline
\end{tabular}

a. Dependent Variable: PBV

Sumber: Hasil Pengolahan Data SPSS 21 (2018)

Berdasarkan hasil uji Tabel 3.8, dapat diketahui nilai $t_{\text {hitung }}$ pada variabel $\mathrm{X}_{1}$ (Debt to Assets Ratio) sebesar 3,600 lebih besar dari $t_{\text {tabel }}$ sebesar 2,03951 atau dapat dikatakan $3,600>2,03951$ dengan taraf signifikan 0,001 lebih kecil dari nilai $\alpha=0,050$, maka $\mathrm{H}_{0}$ ditolak yang artinya debt to assets ratio berpengaruh signifikan terhadap price to 
book value pada Perusahaan Sub Sektor Otomotif yang terdaftar di Bursa Efek Indonesia periode 2013-2017.

Nilai thitung pada variabel $\mathrm{X}_{2}$ (Total Assets Turn Over) sebesar 0,393 lebih kecil dari tabel sebesar 2,03951 atau dapat dikatakan 0,393 $<2,03951$ dengan taraf signifikan 0,697 lebih besar dari nilai $\alpha=0,050$, maka $\mathrm{H}_{0}$ diterima yang artinya total assets turn over berpengaruh tidak signifikan terhadap price to book value pada Perusahaan Sub Sektor Otomotif yang terdaftar di Bursa Efek Indonesia periode 2013-2017.

Nilai thitung pada variabel $\mathrm{X}_{3}$ (Return On Assets) sebesar 8,373 lebih besar dari $t_{\text {tabel }}$ sebesar 2,03951 atau dapat dikatakan 8,373 $>2,03951$ dengan taraf signifikan 0,000 lebih kecil dari nilai $\alpha=0,050$, maka $H_{0}$ ditolak yang artinya return on assets berpengaruh signifikan terhadap price to book value pada Perusahaan Sub Sektor Otomotif yang terdaftar di Bursa Efek Indonesia periode 2013-2017.

\subsection{Evaluasi}

3.2.1. Evaluasi Debt to Assets Ratio Pada Perusahaan Sub Sektor Otomotif dan Komponen yang Terdaftar di Bursa Efek Indonesia Periode 20132017

Dari hasil penelitian menunjukkan bahwa DAR pada Perusahaan Sub Sektor Otomotif dan Komponen yang terdaftar di Bursa Efek Indonesia periode 2013-2017 mengalami fluktuasi dan cenderung menurun. Hal ini dipengaruhi oleh total utang dan total aset mengalami peningkatan tetapi total aset meningkat jauh lebih tinggi yang berupa kas, piutang usaha, persediaan, investasi, properti dan aset tetap lainnya dibanding dari total utang berupa utang usaha, pinjaman bank, liabilitas imbalan kerja dan pajak tangguhan, sewa pembiayaan dan utang lainnya.

Berdasarkan dari hasil penelitian, perusahaan sebaiknya untuk mengurangi jumlah utang dan mengatur tingkat pembelanjaan pada aset sehingga tidak menimbulkan jumlah utang yang besar dan meningkatkan tambahan modal pada perusahaan.

\subsubsection{Evaluasi Total Assets Turn Over Pada Perusahaan Sub Sektor Otomotif dan Komponen yang Terdaftar di Bursa Efek Indonesia Periode 2013-2017}

Hasil penelitian ini menunjukkan bahwa kondisi Total Assets Turn Over (TATO) pada Perusahaan Sub Sektor Otomotif dan Komponen yang terdaftar di Bursa Efek Indonesia periode 2013-2017 mengalami fluktuasi dan cenderung menurun. Hal ini dipengaruhi oleh penjualan dan total aset mengalami peningkatan tetapi total aset meningkat jauh lebih tinggi yang berupa kas, piutang usaha, persediaan, investasi, properti dan aset tetap lain dari penjualan.

Berdasarkan dari hasil penelitian ini, dapat diketahui bahwa tingkat TATO yang maksimum dapat memberikan dampak positif bagi perusahaan, semakin besar tingkat kemampuan perusahaan dalam menjamin penjualan maka akan semakin efektif dalam pengelolaan aset yang dimiliki. Perusahaan dengan tingkat TATO yang rendah sebaiknya meningkatkan pengelolaan seluruh aset perusahaan yang digunakan untuk meningkatkan penjualan dapat berdampak pada peningkatan laba perusahaan yang akan menjadi signal positif bagi investor atau calon investor untuk menambah modalnya.

3.2.3. Evaluasi Return On Assets Pada Perusahaan Sub Sektor Otomotif dan Komponen yang Terdaftar di Bursa Efek Indonesia Periode 20132017

Dari hasil penelitian, dapat diketahui bahwa tingkat Return On Assets (ROA) pada Perusahaan Sub Sektor Otomotif dan Komponen yang Terdaftar di Bursa Efek Indonesia periode 2013-2017 mengalami fluktuasi dan cenderung menurun. Hal ini disebabkan oleh peningkatan total aset lebih tinggi yang berupa kas, piutang usaha, persediaan, investasi, properti dan aset tetap lain dibanding dengan laba bersih setelah pajak. Penurunan laba bersih setelah pajak 
dikarenakan presentase pendapatan lebih rendah dari biaya perusahaan.

Berdasarkan dari hasil penelitian, untuk meningkatkan nilai ROA sebaiknya perusahaan meningkatkan pengelolaan aset untuk memperoleh laba yang lebih maksimal dan mengefisiensi beban operasional perusahaan agar dapat meningkatkan nilai perusahaan sehingga dapat menarik para investor untuk berinvestasi pada perusahaan.

3.2.4. Evaluasi Price to Book Value Pada Perusahaan Sub Sektor Otomotif dan Komponen yang Terdaftar di Bursa Efek Indonesia Periode 20132017

Hasil penelitian ini menunjukkan bahwa nilai Price to Book Value (PBV) pada Perusahaan Sub Sektor Otomotif dan Komponen yang Terdaftar di Bursa Efek Indonesia periode 2013-2017 mengalami fluktuasi dan cenderung menurun. Hal ini dipengaruhi oleh peningkatan nilai buku tidak diikuti oleh harga saham. Peningkatan nilai buku disebabkan sebagian perusahaan mengalami peningkatan pada ekuitas biasa.

Berdasarkan hasil penelitian untuk meningkatkan nilai PBV sebaiknya perusahaan meningkatkan kinerja keuangan dalam mengelola dan menggunakan aset, utang dan ekuitas perusahaan dengan baik yang akan menghasilkan profitabilitas perusahaan dengan maksimal.

\section{KESIMPULAN DAN SARAN}

\subsection{Kesimpulan}

Dari hasil pengujian analisis dan hipotesis yang telah dibahas pada bab sebelumnya, maka penulis menarik beberapa kesimpulan sebagai berikut:

1. Nilai rata-rata DAR pada Perusahaan Sub Sektor Otomotif dan Komponen yang Terdaftar di Bursa Efek Indonesia periode 2013-2017 mengalami fluktuasi dan cenderung menurun. Nilai DAR minimum terdapat pada PT Indospring, Tbk (INDS) tahun 2017. Nilai DAR maksimum terdapat pada PT Nipress, Tbk (NIPS) tahun 2013.
2. Nilai rata-rata TATO pada Perusahaan Sub Sektor Otomotif dan Komponen yang Terdaftar di Bursa Efek Indonesia periode 2013-2017 mengalami fluktuasi dan cenderung menurun. Nilai minimum TATO terdapat pada PT Prima Alloy Steel Universal, Tbk (PRAS) tahun 2017. Nilai maksimum TATO terdapat pada PT Nipress, Tbk (NIPS) tahun 2013.

3. Nilai rata-rata ROA pada Perusahaan Sub Sektor Otomotif dan Komponen yang Terdaftar di Bursa Efek Indonesia periode 2013-2017 mengalami fluktuasi dan cenderung menurun. Nilai minimum ROA terdapat pada PT Gajah Tunggal, Tbk (GJTL) tahun 2015. Nilai maksimum ROA terdapat pada PT Astra International, Tbk (ASII) tahun 2013.

4. Nilai rata-rata PBV pada Perusahaan Sub Sektor Otomotif dan Komponen yang Terdaftar di Bursa Efek Indonesia periode 2013-2017 mengalami fluktuasi dan cenderung menurun. Nilai minimum PBV terdapat pada PT Indospring, Tbk (INDS) tahun 2015. Nilai maksimum PBV terdapat pada PT Astra International, Tbk (ASII) tahun 2013.

5. Dari hasil pengujian analisis regresi linear berganda menunjukkan bahwa debt to assets ratio, total assets turn over dan return on assets berpengaruh positif terhadap price to book value pada Perusahaan Sub Sektor Otomotif dan Komponen yang Terdaftar di Bursa Efek Indonesia periode 2013-2017.

6. Hasil uji koefisien korelasi diperoleh nilai korelasi ( $r$ ) terlihat bahwa terdapat hubungan yang sangat kuat antara variabel debt to assets ratio, total assets turn over dan return on assets dengan price to book value. Sementara koefisien determinasi ( $R$ Square) terlihat bahwa tinggi rendahnya PBV dapat dijelaskan oleh variabel ROA, DAR dan TATO sebesar $75,2 \%$ sedangkan sisanya $25,8 \%$ dijelaskan oleh faktor lainnya yang tidak dijelaskan dalam penelitian ini seperti 
DER, perputaran persediaan, ROE dan faktor lainnya.

7. Dari hasil uji $F$ diperoleh hasil $F_{\text {hitung }}>$ $F_{\text {tabel }}$ dengan taraf signifikan $<0,05$ maka $\mathrm{H}_{0}$ ditolak, artinya bahwa debt to assets ratio, total assets turn over dan return on assets berpengaruh signifikan terhadap price to book value pada Perusahaan Sub Sektor Otomotif dan Komponen yang terdaftar di Bursa Efek Indonesia periode 2013-2017.

8. Dari hasil uji $\mathrm{t}$ diperoleh nilai $t_{\text {hitung }} u$ tuk variabel debt to assets ratio lebih besar dari $t_{\text {tabel }}$ dengan taraf signifikan lebih kecil dari nilai $\alpha=0,050$, maka $\mathrm{H}_{0}$ ditolak yang artinya debt to assets ratio berpengaruh signifikan terhadap price to book value pada Perusahaan Sub Sektor Otomotif yang terdaftar di Bursa Efek Indonesia periode 2013-2017. Nilai $t_{\text {hitung }}$ untuk variabel total assets turn over lebih kecil dari $t_{\text {tabel }}$ dengan taraf signifikan lebih besar dari nilai $\alpha=0,050$, maka $\mathrm{H}_{0}$ diterima yang artinya total assets turn over berpengaruh tidak signifikan terhadap price to book value pada Perusahaan Sub Sektor Otomotif yang terdaftar di Bursa Efek Indonesia periode 2013-2017. Nilai $t_{\text {hitung }}$ untuk return on assets lebih besar dari $t_{\text {tabel }}$ dengan taraf signifikan 0,000 lebih kecil dari nilai $\alpha=$ 0,050 , maka $\mathrm{H}_{0}$ ditolak yang artinya return on assets berpengaruh signifikan terhadap price to book value pada Perusahaan Sub Sektor Otomotif yang terdaftar di Bursa Efek Indonesia periode 2013-2017.

\subsection{Saran}

Berdasarkan kesimpulan dan hasil penelitian di atas, maka penulis memberikan beberapa saran yaitu sebagai berikut:

1. Perusahaan Sub Sektor Otomotif dan Komponen sebaiknya untuk mengurangi jumlah utang, mengatur tingkat pembelanjaan pada aset sehingga tidak menimbulkan jumlah utang yang besar dan meningkatkan tambahan modal.
2. Perusahaan untuk meningkatkan nilai TATO sebaiknya meningkatkan pengelolaan seluruh aset perusahaan yang digunakan untuk meningkatkan penjualan dapat berdampak pada peningkatan laba perusahaan yang akan menjadi signal positif bagi investor atau calon investor untuk menambah modalnya.

3. untuk meningkatkan nilai ROA sebaiknya perusahaan meningkatkan pengelolaan aset untuk memperoleh laba yang lebih maksimal dan mengefisiensi beban operasional perusahaan agar dapat meningkatkan nilai perusahaan sehingga dapat menarik para investor untuk berinvestasi pada perusahaan.

4. Perusahaan Sub Sektor Otomotif dan Komponen untuk meningkatkan nilai PBV sebaiknya perusahaan meningkatkan kinerja keuangan dalam mengelola dan menggunakan aset, utang dan ekuitas perusahaan dengan baik yang akan menghasilkan profitabilitas perusahaan dengan maksimal.

\section{DAFTAR PUSTAKA}

Astuti, Dewi. 2004. Manajemen keuangan Perusahaan. Cetakan Pertama. Jakarta: Ghalia Indonesia.

Brigham, Eugene F. Dan Joel F. Houstan. 2010. Dasar-dasar Manajemen Keuangan. Buku 1. Edisi Ke-10. Jakarta: Salemba Empat.

Horne, James C. Van dan John M. Wachowicz. 2012. Prinsip-Prinsip Manajemen Keuangan. Edisi XII. Jilid I. Jakarta: Salemba Empat.

Kasmir. 2010. Pengantar Manajemen Keuangan, Edisi Ke-1, Cetakan Ke-1. Jakarta: Kencana.

Martani, Dwi, dkk. 2012. Akuntansi Keuangan Menengah Berbasis PSAK. Buku 1. Jakarta: Salemba Empat.

Munawir, Slamet. 2010. Analisis Laporan Keuangan. Edisi Keempat. Yogyakarta: Liberty.

Rudianto. 2012. Pengantar Akuntansi. Konsep dan Teknik Penyusunan 
Laporan Keuangan. Jakarta: Penerbit Erlangga.

Subramanyam, K.R dan John J. Wild. 2010. Analisis Laporan Keuangan. Edisi X. Jakarta: Salemba Empat.
Sudana, I Made. 2011. Manajemen Keuangan Perusahaan Teori dan

Praktek. Jakarta: Penerbit Erlangga. 